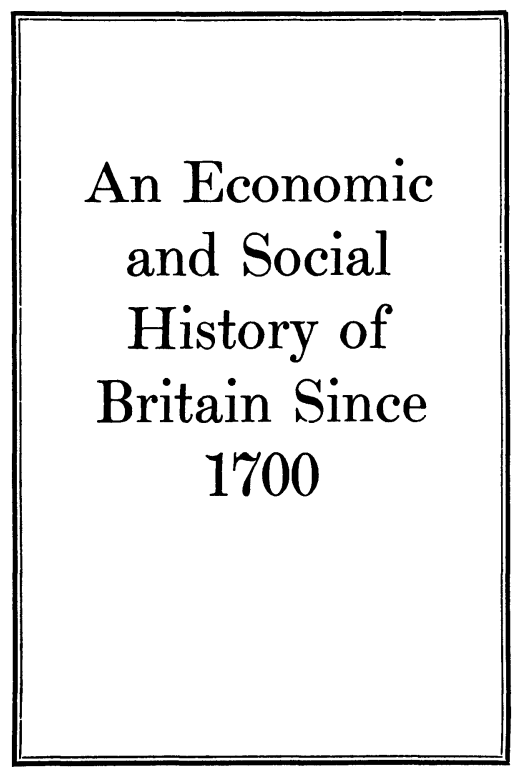


Macmillan books by the same author

An Economic and Social History of Britain, 1066-1939

Readings in Economic and Social History

British Population Growth, 1700-1850

Public Health Reform 


\section{An Economic and Social History \\ of Britain \\ Since 1700}

by M. W. Flinn

Professor of Social History in the

University of Edinburgh

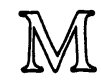

Macmillan Education 
(C) M. W. Flinn 1963 and 1975

All rights reserved. No part of this publication may be reproduced or transmitted, in any form or by any means, without permission

First edition 1963

Reprinted 1965, 1966, 1968, 1970

Second edition 1975

Published by

MACMILLAN EDUCATION LIMITED

London and Basingstoke

Associated companies and representatives throughout the world

ISBN 978-1-349-00025-8 ISBN 978-1-349-00023-4 (eBook)

DOI 10.1007/978-1-349-00023-4 


\section{Contents}

PART ONE THE INDUSTRIAL REVOLUTION

1 A dynamic economy

1 - The British economy of the early eighteenth century

2. Population growth

3. The supply of capital

4 - The rise of banking

5 - The growth of demand

6 - Science and technology

2 Transport and trade

1 - Industrial transport in the early

eighteenth century

$2 \cdot$ River navigation

3. Canals

4. Roads

5. Overseas trade

3 Industry

$1 \cdot$ Iron and steel

2. Engineering

3. Coal

4. Cotton

5 - Pottery

4 Agriculture

1 - Farming in the early eighteenth century

2 - The limitations of open-field farming 3 - New farming techniques

4. Enclosures 52

5 - The results of enclosures $\quad 56$

5 The war economy: 1793-1815

1. Britain and the French Revolution 58

2. Economic effects of the war $\quad 59$

$3 \cdot$ Currency and inflation 62

6 Ideas and social movements

1 - Laissez-faire

65

$2 \cdot$ Radicals and philanthropists $\quad 67$

3. The churches 71

4. Early social reforms 72

15

16

18

23

27

5 - The rise of the trade unions

7 The condition of the working class

1. The factory system $\quad 76$

2. Town life 78

3. The Poor Law 82

4. Britain in depression: 1815-19 85

5. Working-class agitation 86

6. The standard of living $\quad 88$

PART TWO THE NINETEENTH CENTURY

8 The framework of industrial Britain
1 - Britain's industrial lead

2 - The trade cycle

3 - Long-run trends

4. Banking
93

95

97

98 


\section{Transport}

$1 \cdot$ The evolution of the locomotive

2. The early railways

101

3. Problems of the early railways

4. The economic and social

consequences of railway building

$5 \cdot$ Shipping

10 Overseas trade

1. The development of overseas trade 114

2. The Free Trade Movement

115

3 - The movement for tariff reform

119

11 Industrial developments

1. Iron and steel

121

2. Coal

3 - Engineering

4. Cotton

5. The organisation of industry

12 Agriculture

1. Agriculture under the Corn Laws

2 - 'High Farming'

3 - Foreign competition

13 Working-class movements

1. The Co-operative movement

2. Chartism

142

3. The trade unions to 1868

4. The trade unions 1868-1914

14 People and towns

1 - The growth of population

151

2. Migration

152

3. Urban growth

153

4. The beginnings of torwn planning 156
15 Social developments

1 - Parliamentary reform $\quad 160$

2. Education 161

3 - The relief of poverty after $1834 \quad 164$

4. Factory reform 167

5. Public health and housing $\quad 170$

6. Municipal enterprise 172

7. Trends in living standards 174

PART THREE THE TWENTIETH CENTURY

16 Trends

1 - The First World War and the 1920s

178

2 - The depression of the early 1930 s 180

3. Recovery in the 1930s

182

4. The Second World War

184

5 - Groroth since 1945

185

17 Economic developments

1. The old industries

188

2. The nerw industries

192

3. Agriculture

196

4. Transport

198

$5 \cdot$ Overseas trade

201

18 The government and the economy

1 - The First World War and the 1920s

2. The crisis of 1931 and the erosion

of laissez-faire

3 - The Second World War and after 209

19 Social problems, policies and achievements

1. Population trends

214

2 - Unemployment

215

3. The Welfare State

218

4. Labour relations

222

5 - Trends in living standards

225 
MAPS

Distribution of population in $\mathbf{1 7 0 0}$

Distribution of population in 1801

Navigable rivers in England and Wales 1600-60

Navigable rivers in England and Wales 1724-7

Merseyside in the eighteeeth century

Turnpike roads around Birmingham 1725-1830
The flow of goods outwards from the Old World in the first half of the eighteenth century

5 The flow of goods outwards from the New

5 World in the first half of the eighteenth century

29

17

The distribution of furnaces and iron

forges in the early eighteenth century

32

Main centres of the wool-textile

17 industry and their principal products

$21 \quad c \mathbf{1 7 0 0}$

Withdrawal of railway passenger services

25 by British Rail in the 1960s 
The author's thanks are due to the following authors and publishers for permission to quote from the works mentioned:

D. Read, Peterloo: the Massacre and its Background (Manchester University Press, 1958); Friedrich Engels, The Condition of the Working Class in England, translated by W. H. Chaloner \& W. O. Henderson (Blackwell, 1958); C. Morris (editor), The Journeys of Celia Fiennes (Cresset Press, 1947).

The author and publishers wish to thank the following for permission to reproduce photographs, portraits and prints:

Aerofilms Ltd pp. 47, 124, 154, 157 bottom

Beamish North of England Open Air Museum pp. 103, 123

Bedfordshire County Council p. 55

P. J. Bowden p. 40 (from The Wool Trade in Tudor and Stuart England)

British Leyland p. 193 right

British Motor Corporation Ltd p. 193 left

British Museum pp. 41, 127 top, 135, 139, 168

British Railways Board p. 200

British Steel Corporation p. 191 both

Cambridge University Library p. 16

Central Electricity Generating Board pp. 186, 187

Dr S. D. Chapman p. 42

Crown Copyright p. 53 both

Delegates to the Clarendon Press, Oxford p. 17 (from

Willan: River Navigation in England)

Edinburgh University Press p. 32

Elliott and Fry Ltd p. 120

R. B. Fleming p. 111

Fox Photos p. 217 bottom

Greater London Council pp. 157 top, 225 both

Illustrated London News pp. 129 top and bottom, 166 top
Industrial Archaeology Journal p. 171

Philip J. Kelly p. 105

Lancashire Record Office p. 83

Liverpool Corporation p. 166 bottom

London Express pp. 206, 207

Manchester Public Libraries pp. 79 top and bottom, 155

Mansell Collection pp. 38, 60, 68, 87, 94 top, 104, 145, 156, 158

165 bottom

Mary Evans Picture Library p. 94 bottom

National Coal Board p. 169

National Maritime Museum p. 30

National Portrait Gallery p. 118

Pilkington Brothers Ltd p. 131

Radio Times Hulton Picture Library pp. 33, 69, 107, 128, 137, 197, 116, 117 top, 218, 223 top and bottom

G. D. Ramsay pp. 28, 29 (from English Overseas Trade during the Centuries of Emergence)

Science Museum pp. 34, 36

Shell Photographic Service p. 195

Syndics of the University Press, Cambridge p. 5 (from

Darby: An Historical Geography of England Before 1800)

University of Reading Museum of English Rural Life: pp. 51, 136, 196

University Tutorial Press pp. 22, 26, 42

Josiah Wedgwood and Sons Ltd p. 45

Westminster Bank p. 10

The publishers have made every effort to trace copyright-holders, but if they have inadvertently overlooked any, they will be pleased to make the necessary arrangement at the first opportunity. 